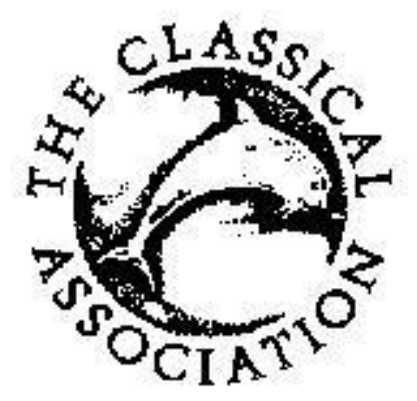

Antipater after the Lamian War: New Readings in Vat. Gr. 73 (Dexippus fr. 33) Author(s): Gunther Martin

Source: The Classical Quarterly, Vol. 55, No. 1 (May, 2005), pp. 301-305

Published by: Cambridge University Press on behalf of The Classical Association Stable URL: https://www.jstor.org/stable/3556259

Accessed: 16-09-2019 12:32 UTC

JSTOR is a not-for-profit service that helps scholars, researchers, and students discover, use, and build upon a wide range of content in a trusted digital archive. We use information technology and tools to increase productivity and facilitate new forms of scholarship. For more information about JSTOR, please contact support@jstor.org.

Your use of the JSTOR archive indicates your acceptance of the Terms \& Conditions of Use, available at https://about.jstor.org/terms

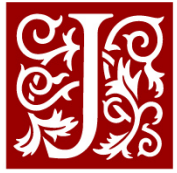

Cambridge University Press, The Classical Association are collaborating with JSTOR to digitize, preserve and extend access to The Classical Quarterly 
procedural change, post Herodotus, ${ }^{10}$ in respect of the hippeis and the agathoergoi is a question I leave for contemplation by experts in that area.

Queen's University, Belfast

DAVID WHITEHEAD

d.whitehead@qub.ac.uk

doi:10.1093/cq/bmi023

\section{ANTIPATER AFTER THE LAMIAN WAR: NEW READINGS IN VAT. GR. 73 (DEXIPPUS FR. 33)*}

When the Greeks of the imperial era looked back to the golden age of their nation, it was mainly to the period between the Persian wars and Alexander that they looked. Although he caused the dissemination of Greek culture to a previously unknown extent, the Macedonian king, by putting an end to the freedom of the Greek poleis, at the same time marked the end of Hellas in its classical form. Accordingly, only two Greek historical monographs of the imperial period are known to deal with the events following his death. ${ }^{1}$ The two works by Arrian and Dexippus containing $\tau \dot{\alpha}$

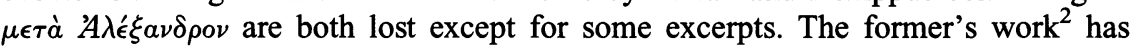
been summarized by Photius in the Bibliotheca, so that we know its general design. It seems that he started with the division of the huge empire immediately after Alexander died in 323. In Photius' (not necessarily very reliable) ${ }^{3}$ account five of the ten books are largely filled by the Lamian War and other uprisings in Thrace and Cappadocia. Some further quotations in the Suda add nothing substantial to our knowledge of the work. The second work, that of Dexippus of Athens, ${ }^{4}$ is also mentioned by Photius, who again lists the commanders of the Macedonian army and their share of the empire immediately after Alexander's death (F 8, with minor deviations from Arrian). Photius does not recount anything more, but states that the rest is in agreement $\left(\sigma v^{\prime} \mu \omega \nu \alpha\right)$ with Arrian's treatment. However, we have a number of fragments of this text in the Excerpta de sententiis, commissioned by Constantine VII of Byzantium (906-9) and transmitted in a palimpsest in the Vatican Library (Vat. gr. 73).

It has been almost a hundred years since Boissevain published the first (and still the only) edition of the text that meets modern standards. ${ }^{5}$ He was able to give a far better text than the one Mai had published in the editio princeps of $1828 .^{6}$ However, portions of the History after Alexander were on folia that have not been preserved.

10 A theoretical alternative is that the procedure Herodotus describes is plain wrong, i.e. that it was selection $\kappa a \tau^{\prime}{ }^{\prime}{ }^{\prime} \delta \rho a \gamma \alpha \theta_{i}{ }^{\prime} a v$ all along; but in that event we could have expected the sort of stern correction, of Herodotean misconceptions about Sparta, famously meted out by Thucydides (1.20.3: the kings' votes and the Pitanate lochos).

* I would like to express my thanks to the editors of $C Q$ and Professor Pelling for their suggestions, and the Franz-Marie-Christinen Foundation Regensburg for a grant for my trip to Rome.

1 There is one other possible work on the successors, an abstract of which has been preserved ( $F G r H 155$, the 'Heidelberger Epitome'). The period of its composition is, however, unknown. Other authors writing on this topic (Hieronymus of Cardia, Nymphis of Heracleia) lived in the fourth and third centuries B.C.

2 References are to the edition of A. G. Roos and G. Wirth (Leipzig, 1968).

3 P. A. Brunt, 'On historical fragments and epitomes', $C Q$ n.s. 30 (1980), 477-94.

4 The fragment numbers follow $\mathrm{FGrH} 100$.

${ }^{5}$ Ursul Boissevain, Excerpta historica iussu imp. Constantini Porphyrogeniti confecta. 4: Excerpta de sententiis (Berlin, 1906).

${ }^{6}$ Angelo Mai, Scriptorum veterum nova collectio e Vaticanis codicibus 2 (Rome, 1828). 
More than that, owing to the chemicals Mai used to make the scriptio inferior legible, one page of fragments has in large part become too dark to make decipherment of the text possible. Thus, what we have are passages from speeches that purport to have been delivered by Hypereides and an unknown opponent ${ }^{7}$ on whether or not to undertake the Lamian War, a commentary on this war by the author himself, and, on the barely legible page, a number of seriously mutilated single sentences. The latter seem to be concerned with envoys asking for peace. Thanks to the technological achievements of the last century, it is possible to supplement the readings that Boissevain provided.

The use of an ultraviolet lamp cannot completely make up for the condition of the parchment, which deteriorates with the lapse of time and with every use. However, some passages are more or less clearly legible. On a visit to the Vatican Library, I had the opportunity to apply this technique to the manuscript and to obtain some new readings. The following text is a combination of these readings and Boissevain's edition. Some further alterations have been added. ${ }^{8}$

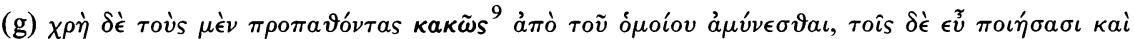

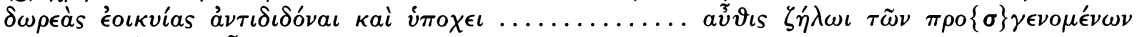

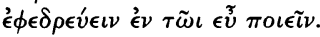

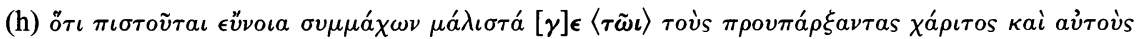

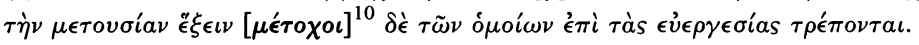

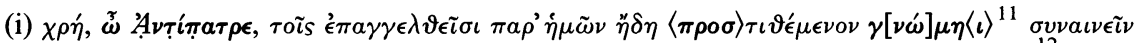

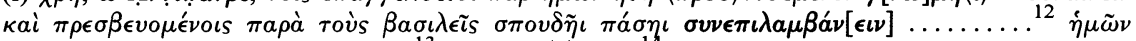

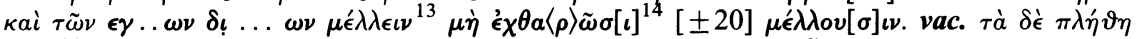

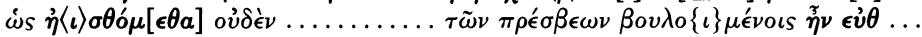

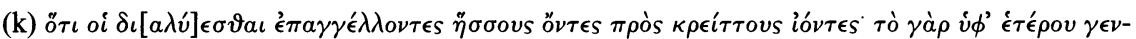

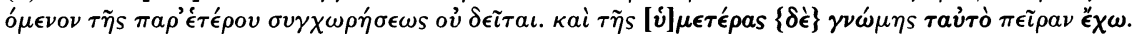

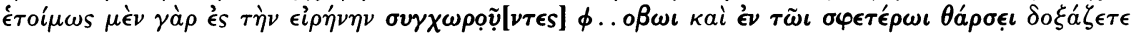

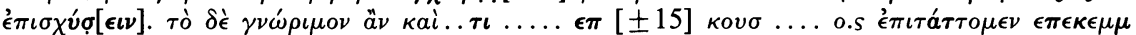

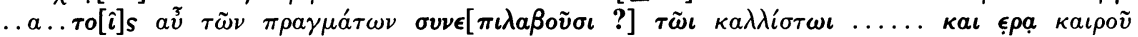

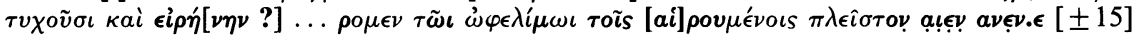

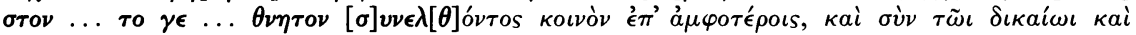

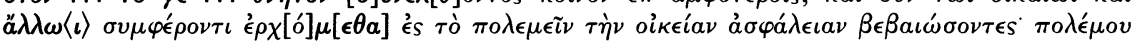

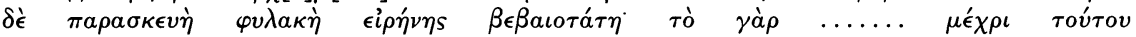
...................... $\mu \eta \dot{\delta} \dot{\epsilon} \nu \pi \rho a ́ \xi \epsilon \iota \nu$.

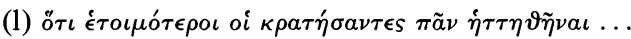

It is very likely that fragments $33(\mathrm{~g})-(1)$ all come from speeches, and the position in the manuscript suggests that the setting is after the Athenian decision to start the

7 Jacoby on F 32-6 suggested that this was Phocion.

8 Boissevain reproduced some of his own readings in his apparatus without incorporating them in the main body of his edition. Those that are used here are not specially marked. His text also includes readings by Mai of portions that are now illegible. Passages in which the new text differs from Boissevain's are printed in bold.

9 The manuscript has kai $\dot{\omega} s$. I owe this suggestion to Professor Christopher Pelling. The parallel in F 32(h) confirms it. There seems, however, to be no other instance of $\kappa a \kappa \tilde{\omega} s \pi \rho o^{-}$ $\pi \alpha ́ \sigma \chi \epsilon \iota \nu$ in Greek literature.

${ }_{10}$ This is not meant to be a conjecture, but indicates what sense we would expect from the missing word(s). The manuscript seems to have $\epsilon . \epsilon \rho \epsilon \pi \iota$.

11 Throughout the manuscript, the use of iota adscript is inconsistent.

12 Boissevain gives $\pi \epsilon \rho \tau \iota \sigma o \iota$; I read something like . $\mu \pi . \rho \sigma \eta \tau o \iota$.

13 It seems that Boissevain here skipped one line (from $\mu \epsilon \epsilon \lambda \epsilon \iota \nu$ to $\mu \epsilon^{\prime} \lambda \lambda o v \sigma \iota v$ ).

14 The manuscript has $\epsilon \chi \vartheta \eta \omega \sigma$. 
Lamian War (described in (f)), but how long after is not clear. If the content of Dexippus' work was similar to Arrian's, it included the events up to Antipater's return to Macedonia in 321/0. Nevertheless, Jacoby interpreted the fragments as part of the narrative of the Lamian War, and Boissevain, too, thought they belonged

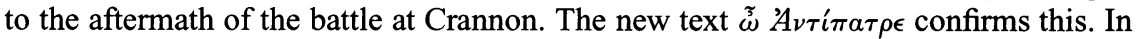
the following, I hope to suggest two possible historical settings of the fragments.

In fragment (i), we do not know the speaker, but the addressee can now be identified: Antipater is asked to agree to some promises or announcements made by the speaking party. If we take $\dot{\epsilon} \pi a \gamma \gamma \gamma^{\prime} \lambda \lambda o \nu \tau \epsilon s$ at the beginning of fragment (k) as a reply to $\tau \circ \tilde{\iota}_{\iota} \stackrel{\dot{\epsilon} \pi}{\pi} \alpha \gamma \gamma \in \lambda \vartheta \epsilon \tilde{\epsilon} \sigma \iota$ in the preceding fragment, it is clear that the offer in (i) is of peace between the speakers and Antipater.

Furthermore, the Macedonian general is asked to support (or even take part in) an embassy to 'the kings'. The Macedonian kings at that time were Alexander's newborn son Alexander and his brother Arridaeus, though power rested with Perdiccas (Arrian, Alex. F 1.3). In the case of Samos, we learn that Antipater left the decision on the fate of the island after the Lamian War to the kings, that is to their guardian (Diod. Sic. 18.18.6). It is thus possible that envoys would assume that whatever they negotiated with Antipater was subject to approbation by the nominal leaders of the empire and that an embassy to them would be required.

In any case, the speeches were not given (in the historiographical fiction) after Antipater had taken over the guardianship of the kings in 321 (Diod. Sic. 18.39.2). The speaker in (i) mentions 'us': the underlying conflict is therefore a power struggle against several successors of Alexander (not just, for example, Eumenes), or a war against a city or a people. Antipater's answer is a rebuke of the opponents' misrepresentation of the situation. The restoration of the text is difficult, but Antipater seems to say that the opponents need peace and cannot make him believe that they are in a position to ask for concessions. Moreover, he claims to have both justice and expediency on his side. His preparedness to wage war is just a measure to enhance his own security and to stabilize the peace.

If we compare the few allusions to the historical situation of the battle at Crannon, we find possible parallels: Menon and Antiphilus, the generals of the Greeks, sent envoys to Antipater to ask for a settlement. This was refused by Antipater, ${ }^{15}$ who would only make treaties with each city separately. After he and Craterus had seized a number of towns in Thessaly, the Thessalians accepted his conditions (Diod. Sic. 18.17.6-8). Having achieved this, he led his whole army against Athens. The Athenians sent Demades and Phocion (among others) to negotiate, but Antipater accepted only an unconditional surrender, including a change of constitution (Diod. Sic. 18.18.1-4; Plut. Phoc. 26.7).

The speaker of (k) describes the mental attitude of his counterparts as $\vartheta a ́ \rho \sigma o s$, something that Phocion (?) in fragment (d) ascribes to those (Athenians) proposing war. Antipater probably also says that he has experienced his opponents' fickleness, ${ }^{16}$ which could be a description of the whole enterprise of the Lamian War-a proof of Greek unreliability and thirst for independence. His announcement that his side is going to wage war for the sake of their own safety fits the situation in which he

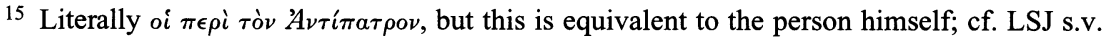
$\pi \epsilon \rho i ́$ C I 2.

16 This must be the meaning of $\gamma \nu \omega \mu \eta \eta$ in this situation. It has been pointed out to me that the word might refer back to (i). There, however, it probably means 'proposal' (cf. Xen. Cyr.

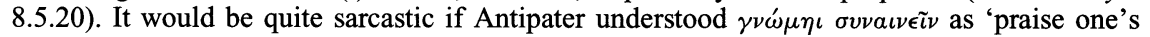
temper', taking up the phrase and using it as criticism.
} 
declined the request for peace and turned to the siege of the Thessalian cities. ${ }^{17}$ It could as well be the reply to the Athenians, who tried to gain better terms for their city (Diod. Sic. 18.18.3). Antipater's claim that his side is fighting a just cause (sc. because they had been attacked first) would easily match Dexippus' categories of justification for war if the point was made in the context of the Lamian War. ${ }^{18}$ Against this background, we can also interpret fragment (1) as a side swipe at the success of the Greek alliance at the start of the war: since it had nearly won the war, it was now liable to suffer total defeat.

In the extant accounts of the first years after Alexander's death, there is no situation that fits our text better than the time after Crannon. Events later on-for example, when Antipater campaigns against Eumenes (Diod. Sic. 18.42.1; Arrian, Alex. F $1.40-1)$ - face greater difficulties. ${ }^{19}$

We are left with fragments $(\mathrm{g})$ and $(\mathrm{h})$. These two obviously go together: in both we hear of the relations between two groups and the return of previous favours. In (h) the groups are specified as allies ( $\sigma \dot{v} \mu \mu a \chi o \iota)$. Either someone is giving advice as to how to treat one's allies or someone is complaining about the absence of due consideration for favours.

It is not obvious whether these fragments belong to the same context as (i)-(l) or somewhere between the start of the war (f) and the peace negotiations. The sources tell us that the Athenians had sent out envoys to the Greek cities to find allies. If the speech(es) were given on this occasion, we might identify the previous favours as the salvation of Greece by Athens in the Persian wars. This is an argument that was indeed brought forward by the Athenians (Diod. Sic. 18.10.3). The reference to an equal share (of something positive, not of the burden of war) in (h), however, must remain obscure and does not fit this historical context.

If the fragments are part of the same speech as (i), it is certainly surprising to see the defeated party speaking of alliance and previous favours, and giving advice as to how to make one's allies benevolent. However, the tone is not alien to that of (i), in which the speaker talks of announcements as if he had made a generous offer to the Macedonians that Antipater ought to support. Antipater's rather brusque rejection also reveals that the rhetoric of his opponents is overconfident. Moreover, Plutarch tells us in his account of Phocion that Antipater indeed offered friendship ( $\left.\varphi \lambda^{\prime} i^{\prime} a\right)$ and an alliance $\left(\sigma v \mu \mu \alpha \chi_{i}^{\prime} \alpha\right)$ to the Athenians on condition that they extradited Demosthenes and Hypereides (Phoc. 27.5). References to these topics are thus not inappropriate and might constitute a justification of the war as a reaction to the fact that the Macedonians did not adequately appreciate the military help provided by the Greeks (or Athenians specifically) during the Persian campaign (or even earlier, if it is the embassy directly after the battle, in which the Thessalians participated).

It is not possible to decide definitely which embassy to Antipater is the setting for the fragments. However, I hope to have shown that the fragments come from an antilogia, and in what situation the speeches are given. Antipater's remark that he is going to make war for the sake of safety might fit better into the situation immediately after the battle at Crannon when he was about to seize the Thessalian cities.

17 In Diodorus (18.17.7) he starts the assault only after the Greeks had refused his conditions, but the account is very brief and does not exclude the possibility that Antipater threatened further military action from the start.

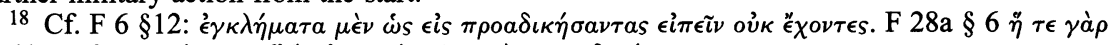

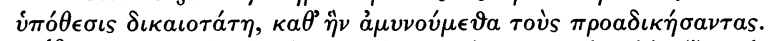

19 For example, the first- and second-person plural in (i) and (k) as well as the embassy to the kings. 
However, even though he did not directly threaten to attack Athens (Plut. Phoc. 26.57 ), this comment would not be totally out of place in the negotiations with Phocion and Demades.

Finally, I would like to oppose the view that the History after Alexander idealized the past (in particular of Dexippus' home town Athens).$^{20}$ It is true that all the surviving excerpts from the work are concerned with this city: ${ }^{21}$ fragments $32,33(\mathrm{a})-(\mathrm{e})$, and 34-6 deal with the Athenian decision to go to war, 33(f) with the general nature of this war, and 33(g)-(l) with peace negotiations in which Athenians are involved one way or other. ${ }^{22}$ However, the basic tendency is not favourable to the Athenian decision. Dexippus stresses in his own voice how unreasonable it was to start the war considering the difference of military strength (F 33(f)). Only irrational

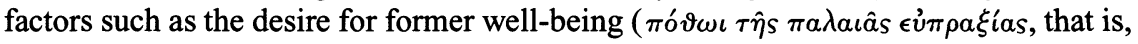
probably, glory and freedom) made them (either the Athenians alone or together with their allies) start the war.

Moreover, there are parallels between the fragments discussed above and a pair of speeches from Dexippus' Scythica (F 6): in that fragment a delegation of Germanic Juthungi comes to the emperor Aurelian after a decisive defeat (in A.D. 271) to ask for peace. However, since they do not want to lose the tribute the Romans pay to them, they boast about their men and military power, threatening the Romans if they are not granted free retreat. Just like the defeated party in F 33, they claim to have done services to the other side and to deserve good treatment, including a renewed alliance. More striking is the similarity of the answers. Aurelian teaches the barbarians a lesson in how a defeated army should refrain from arguing or making requests. In both cases the second speaker humiliates his opponents by highlighting their misrepresentation of the situation. And in both cases the speaker threatens to continue military action. Thus, Dexippus describes the position of the Athenians and the tenor of their speech in terms in which he also presents barbarians after a crushing defeat.

We should therefore reconsider the character of the History after Alexander. The Lamian War might have been an important episode in the work, but Dexippus certainly did not glorify the last battle for Greek freedom. Even though we are not likely to find substantial new parts of the text, ${ }^{23}$ we have to reckon that the four books did not simply focus on the early history of the author's home town.

Balliol College, Oxford

GUNTHER MARTIN gunther.martin@balliol.ox.ac.uk doi: $10.1093 / \mathrm{cq} / \mathrm{bmi024}$

${ }^{20}$ E. V. Maltese, 'Iperide, Tucidide, i $M \epsilon \tau$ ' 'A $\lambda \dot{\epsilon} \xi \alpha \nu \delta \rho o \nu$ di Dessipo', $A S N P 8$ (1978), 393419, at 418; similarly R. Calabrese, 'La concezione della storia in Dexippo di Atene', Sileno 4 (1978), 129-43, at 130; more cautious is F. Millar's judgement in his classic article 'P. Herennius Dexippus: the Greek world and the third-century invasions', JRS 59 (1969), 12-29, at 22: we cannot know.

${ }^{21}$ Photius' summary (F 8) and a reference in the scholia to Lucian (F 31) prove that the division of the Macedonian empire did indeed play a certain role.

${ }^{22}$ The negotiators are either Demades and Phocion, or Menon of Pharsalus and the Athenian Antiphilus.

${ }^{23}$ There is hope that one day at least the fragments of the Constantinian Excerpts may be read properly. As Boissevain states in his edition (pp. $\mathrm{xx}-\mathrm{xxi}$ ), whenever someone reads the manuscript, he or she will discover new traces of ink or recognize new letters. 